\title{
Analisis Proses Bisnis Sistem Pembuatan Surat Perintah Perjalanan Dinas Kantor Regional II PT.Pos Indonesia
}

\author{
Meza Silvana ${ }^{1}$, Hafiz Fajrin ${ }^{2}$, Danton $^{3}$
}

\begin{abstract}
Official Travel Warrant (SPPD) is the work order given by a supervisor or head office employees to perform work tasks to existing agencies or offices elsewhere. SPPD in the manufacturing process, a government and private agencies still mostly done simply by manual recording using microsoft office help, not to use specific applications to process SPPD. This resulted in the system becomes less effective and efficient. To overcome these problems, need to be built a computerized system of data management processes and employee business travel. The proposed system can assist in making the assignment letter employee business travel, expense management, costing, printing letters and printing receipts duty travel expenses. With a system of computerized information service trips, this can facilitate the agency to make a business trip and trip data management services more better.
\end{abstract}

Intisari- Surat Perintah Perjalanan Dinas (SPPD) merupakan surat perintah kerja yang diberikan oleh atasan atau kepala kantor kepada pegawai untuk melakukan tugas kerja ke instansi atau kantor yang ada di tempat lain. Dalam proses pembuatan SPPD, sebuah instansi pemerintah maupun swasta kebanyakan masih dilakukan secara sederhana dengan pencatatan manual menggunakan bantuan microsoft office, belum menggunakan aplikasi khusus dalam proses pembuatan SPPD. Hal ini mengakibatkan sistem menjadi kurang efektif dan efisien, baik dari segi materi maupun waktu. Untuk mengatasi permasalahan tersebut, perlu dibangun sebuah sistem yang terkomputerisasi proses pengelolaan data perjalanan dinas pegawai. Sistem yang diusulkan tersebut dapat membantu dalam pembuatan surat tugas perjalanan dinas pegawai, pengelolaan biaya, penghitungan biaya, pencetakan surat tugas dan pencetakan kwitansi biaya perjalanan. Dengan adanya sistem informasi perjalanan dinas yang terkomputerisasi ini dapat memudahkan instansi untuk membuat surat perjalanan dinas dan pengelolaan data perjalanan dinas terkelola lebih baik.

Kata Kunci-SPPD, pencatatan, instansi, komputerisasi.

\footnotetext{
Dosen, Jurusan Sistem Informasi Fakultas Teknologi Informasi Universitas Andalas, Kampus Limau Manis Padang 55281 INDONESIA (telp: 0751-5555; fax: 0751-54321; e-mail: mezasilvana@ft.unand.ac.id)

${ }^{2}$ Mahasiswa, Jurusan Sistem Informasi Fakultas Teknologi Informasi Universitas Andalas, Kampus Limau Manis Padang 55281 INDONESIA (telp: 0751-5555; fax: 0751-54321; e-mail: fajrin.hafiz@gmail.com )

${ }^{3}$ Kantor Regional II PT POS INDONESIA (Persero), Padang, Indonesia
}

\section{PENDAHULUAN}

Sistem Informasi merupakan suatu hal yang harus dimiliki oleh suatu organisasi untuk dapat menunjang kegiatan manajerial dan kinerja dalam bidang apapun. Setiap organisasi pasti memiliki sistem informasinya sendiri[1]. Begitu juga pada Kantor Regional II PT.Pos Indonesia (Persero). Selama ini, pada Kantor Regional II PT.Pos Indonesia (Persero), SPPD dikeluarkan setiap kali ada perjalanan dinas. Surat ini penting karena diperlukan untuk dokumentasi dan pencatatan dalam urusan kedinasan pegawai pada PT.Pos Indonesia (Persero) baik daerah maupun pusat.

Proses pembuatan surat perintah perjalanan dinas tersebut masih dilakukan secara sederhana dengan pencatatan manual menggunakan microsoft excel. Dan juga masih terdapat banyak proses yang panjang sehingga tidak efisien dari segi waktu[2][3]. Oleh karena itu, PT. Pos Indonesia (Persero) Kantor Regional II membutuhkan sebuah sistem terkomputerisasi dalam proses pembuatan SPPD menjadi lebih efektif. Untuk mengatasi hal itu, maka dirasa perlu untuk membuat aplikasi khusus dalam pengembangan sistem pembuatan surat perjalanan dinas secara terkomputerisasi sehingga dapat memudahkan instansi untuk membuat surat perjalanan dinas dan pengelolaan data perjalanan dinas[1][4].

\section{TINJAUAN PUSTAKA}

\section{A. Surat Tugas}

Surat tugas adalah naskah dinas dari atasan yang ditujukan kepada bawahan untuk melaksanakan tugas sesuai dengan perintah atasan kepada bawahannya, berisi perintah untuk melaksanakan tugas tertentu.Fungsi dari surat tugas adalah sebagai surat pengantar dalam melaksanakan tugas dalam pekerjaannya, atau surat tugas berfungsi sebagai bukti bahwa oarang yang diberi surat tugas telah memiliki wewenang untuk melakukan tugas yang telah dibebankan kepadanya. Surat tugas juga bermanfaat sebagai bukti bahwa ia pernah menjalankan pekerjaan sebagaimana yang tertuang dalam surat tugas[5][6]. Ada beberapa hal yang harus dimiliki dalam surat tugas, yaitu:

1. Perjalanan dinas oleh pelaksana surat tugas dilakukan sesuai dengan perintah atasan pelaksana surat tugas yang tertuang dalam surat tugas.

2. Surat tugas yang dimaksud diterbitkan oleh Kepala satuan kerja untuk Perjalanan Dinas yang di lakukan oleh pelaksana surat tugas pada satuan kerja.

3. Surat tugas paling sedikit mencantumkan nama pemberi tugas, jenis pelaksanaan tugas, tanggal dan waktu pelaksanaan tugas, dan tempat pelaksanaan tugas. 


\section{B. Surat Perjalanan Dinas}

Surat perjalanan dinas atau dikenal dengan SPPD merupakan jenis surat tugas yang dibutuhkan oleh seorang pegawai dalam melaksanakan tugas kerja dan harus pergi ke daerah lain (misalnya ke luar kota). Tugas kerja tersebut dapat berupa studi banding, audit ke perusahaan cabang, rapat kerja nasional maupun pekerjaan-pekerjaan lain yang dilakukan di luar kota (tidak di lingkungan kantor sendiri). Karena perjalanan kerja ke luar kota membutuhkan biaya tambahan dan itu harus ditanggung oleh perusahaan, maka surat ini dibutuhkan sebagai bukti bahwa seorang pegawai atau karyawan melaksanakan tugas kerja ke luar kota sekaligus juga berfungsi sebagai bukti perintah dari atasan kepada bawahannya untuk melakukan tugas/pekerjaan di luar kota[2][3][7]. Hal-hal yang dicantumkan dalam SPPD antara lain:

1. Pejabat atau Atasan yang memberikan perintah.

2. Pegawai atau Karyawan yang diberikan perintah berikut dengan orang-orang yang ikut dalam perjalanan dinas.

3. Maksud dan Tujuan Perjalanan Dinas.

4. Lamanya perjalanan dinas dilakukan.

5. Tempat asal dan tempat tujuan dinas.

6. Pembebanan Anggaran terhadap biaya perjalanan dinas.

7. Tanda tangan pejabat terkait.

8.Keterangan Perjalanan yang diisi oleh pegawai yang melakukan perjalanan dinas.

\section{Flowmap}

Flowmap merupakan penggambaran secara grafik dari langkah-langkah dan urutan-urutan prosedur dari suatu program. Flowmap efektif digunakan untuk menggambarkan proses maupun prosedur dalam sebuah organisasi[8][9]. Oleh karena itu, untuk menggambarkan cara pembuatan SPPD pada PT. Pos (Persero) Kantor Regional II ini, flowmap digunakan untuk menggambarkan urutan prosedur/proses kerja dalam pembuatan SPPD. Ada beberapa hal yang harus diperhatikan oleh seorang analis dan programmer akan membuat flowmap, diantaranya beberapa petunjuk yang harus diperhatikan secara detail, seperti :

a. Flowmap digambarkan dari halaman atas ke bawah dan dari kiri ke kanan.

b. Durasi waktu aktivitas dimulai dan berakhir harus ditentukan secara jelas.

c. Setiap langkah dari aktivitas harus diuraikan dengan menggunakan deskripsi kata kerja yang jelas.

Ada beberapa jenis Flowmap, di antaranya adalah:
a. Flowmap sistem
b. Flowmap paperwork dan dokumentasi
c. Flowmap skematik
d. Flowmap program
e. Flowmap proses

D. Flow Chart
Flowchart merupakan penggambaran secara fisik dari langkah-langkah dan urutan prosedur dari suatu program. Flowchart dapat membantu analis untuk memecahkan masalah dalam bentuk segmen-segmen yang lebih kecil dan mamudahkan dalam mendapatkan alternatif lain yang dalam proses pengoperasian. Flowchart biasanya digunakan pada penyelesaian suatu masalah terutama masalah yang perlu pembahasan mendalam dan butuh untuk dievaluasi lebih lanjut[8][9][10].

\section{Metodologi Penelitian}

Metode pengumpulan data pada penelitin ini dilakukan dalam beberapa cara, diantaranya[4][7]:

1. Wawancara

Wawancara merupakan metode pengumpulan data yang diperlukan dengan menanyakan secara langsung kepada karyawan atau pekerja pada PT.POS Indonesia (PERSERO) Kantor Regional II.

2. Observasi

Observasi merupakan metode pengumpulan data dengan melakukan pengamatan langsung terhadap suatu permasalahan atau gejala-gejala subyek yang diteliti.

3. Studi Pustaka

Studi Pustaka merupakan cara memperoleh data dengan mempelajari buku-buku, dokumen dan peraturan-peraturan tertulis maupun Surat Keputusan yang ada kaitannya dengan obyek peneliti.

\section{ANALISIS DAN PEMBAHASAN SISTEM}

A. Prosedur awal sistem yang sedang berjalan Prosedur yang sedang berjalan di Kantor Regional II PT. Pos Indonesia (Persero) adalah sebagai berikut:

a. Kepala Regional II memberikan perintah kepada pegawai untuk melakukan tugas perjalanan dinas.

b. Pegawai memberikan pengajuan surat perintah perjalanan dinas kepada Bagian SDM yang disetujui oleh Manager SDM.

c. Setelah disetujui oleh Manager SDM, Kepala Sub Bagian SDM membuat Surat Perintah (Lampiran I), Formulir Bukti perjalanan dinas (Formulir II) Rincian biaya (Formulir III), dan Kuitansi Perjalanan Dinas atas nama pegawai yang bersangkutan.

d. Kepala Sub Bagian SDM membuat surat permohonan kepada Bagian Keuangan untuk pengeluaran biaya perjalanan dinas dengan dilampiri formulir pengajuan yang telah disetujui oleh Manager SDM.

e. Bagian Keuangan meneruskan surat permohonan yang telah disetujui oleh Manager SDM kepada Kepala Sub Bagian Keuangan.

f. Kepala Sub Bagian Keuangan, mengeluarkan uang muka perjalanan dinas sesuai dengan pengajuan.

g. Kepala Sub Bagian SDM mengambil uang muka perjalanan dinas sesuai dengan jumlah pengajuan dan 
memberitahukan kepada pegawai yang akan melaksanakan perjalanan dinas.

h. Pegawai yang akan melaksanakan perjalanan dinas, mengambil biaya perjalanan dinas dengan menandatangani Rincian Biaya dan Kwitansi Perjalanan dinas.

i. Kepala Sub Bagian SDM memberikan Surat Perintah dan Formulir Bukti perjalanan dinas (Formulir II) untuk dimintakan Cap, tanda tangan dan nama pejabat penandatangan pada Instansi tempat tujuan pada saat tiba dan akan kembali dari tujuan.

j. Pegawai yang bersangkutan, membuat Laporan Kegiatan Perjalanan Dinas sesuai lampiran disampaikan kepada Manager SDM sebagai bukti telah selesai melaksanakan perjalanan dinas.

Setelah melakukan analisis awal terhadap prosedur sistem yang sedang berjalan, maka sistem tersebut dapat digambarkan dalam bentuk flowmap seperti pada gambar 3 .

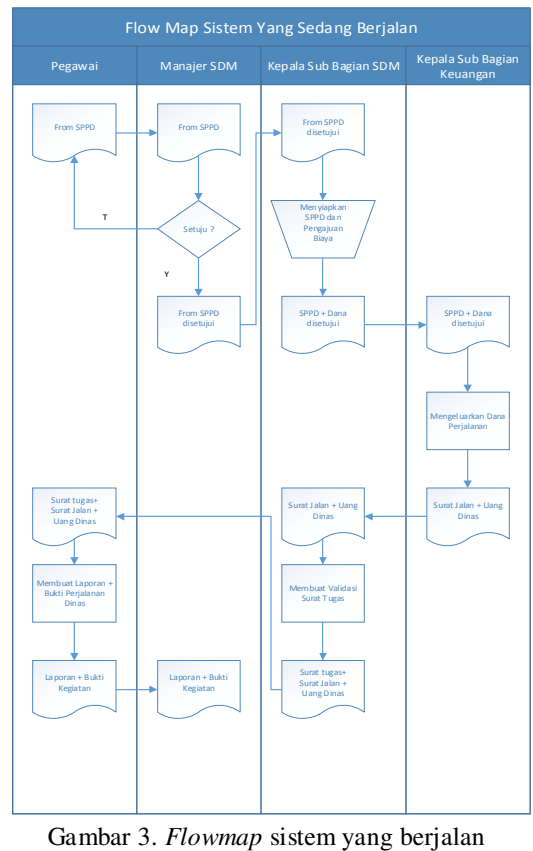

Dari gambar 3 tersebut dapat dilihat bahwa masih terdapat prosedur cukup banyak dan proses berbelit-belit yang harus dilalui oleh pegawai dalam pembuatan SPPD. Proses tersebut akan sangat membingungkan pegawai dan membutuhkan waktu yang relatif lama. Selain itu, pengelolaan data perjalanan dinas yang masih dilakukan secara sederhana menggunakan microsoft excel dan tidak tersimpan dalam database sehingga data yang tersimpan sementara terpisah dalam banyak file, hal ini memyebabkan data rentan hilang, sehingga harus ada sebuah sistem informasi yang mendukung untuk membuat laporan SPPD ini.
B. Sistem terkomputerisasi yang diusulkan

Penelitian ini mengusulkan sistem yang menggunakan sistem tekomputerisasi untuk mengatasi persoalan yang terjadi pada prosedur SPPD yang sedang berjalan tersebut. Prosedur sistem pembuatan surat perintah perjalanan dinas terkomputerisasi yang diusulkan ini terdiri dari beberapa langkah yang dapat dijelaskan sebagai berikut:

1. Pegawai menyerahkan from SPPD dan Pengajuan biaya perjalanan kepada bagian SDM.

2. From SPPD dan pengajuan biaya diterima bagian SDM untuk disetujui oleh Manajer SDM. Kemudian from SPPD dan dan Disetujui Diserahkan kepada operator sistem pembuatan surat perintah perjalanan dinas yang sudah terkomputerisasi.

3. Operator menerima from SPPD dan Dana Disetujui, kemudian operator menginputkan data from SPPD untuk dibuatkan surat tugas, surat jalan dan kwitansi uang dinas.

4. Setelah surat tugas, surat jalan, dan kwitansi uang dinas selesai dicetak, kemudian diserahkan kepada bagian keuangan untuk mencairkan uang perjalanan dinas dan diserahkan kepada pegawai yang akan melakukan perjalanan.

5. Pegawai menerima surat tugas, surat jalan, dan uang perjalanan dinas, lalu membuat laporan kegiatan setelah kembali melakukan perjalanan dinas dan diserahkan kepada bagian SDM.

Dari prosedur di atas alur proses pembuatan SPPD terkomputerisasi yang diusulkan dapat digambarkan dalam bentuk flowmap seperti pada gambar 4 berikut:

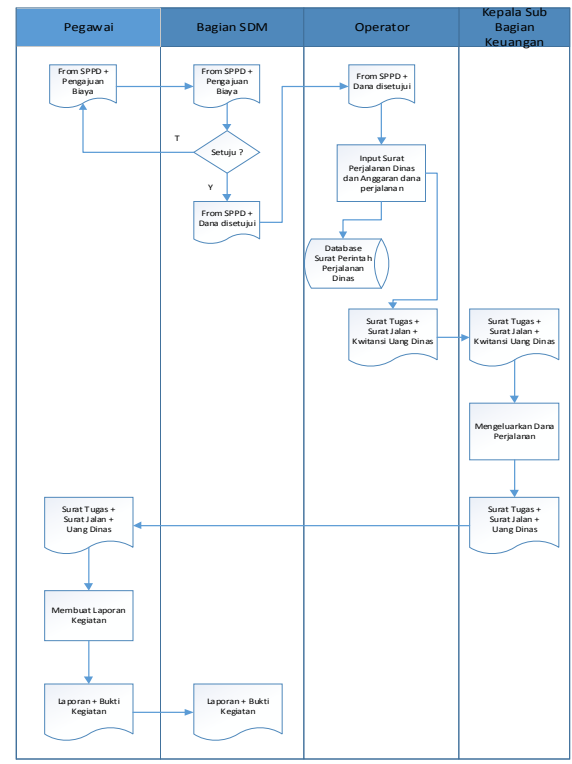

Gambar 4. Flowmap sistem terkomputerisasi yang diusulkan 
Dari gambar 4 dapat dilihat bahwa sistem memotong beberapa prosedur sehingga memudahkan pegawai dalam mendapatkan SPPD, dimana sistem ini memungkinkan pegawai tidak banyak berurusan dengan beberapa orang yang biasanya menyebabkan surat terhenti lama pada tempat tersebut.

Selain dengan flowmap di atas, untuk merancang sistem yang menjadi usulan atau sistem pengganti dari sistem yang sebelumnya yang telah berjalan, maka penulis juga memberikan gambaran dalam bentuk flowchart mengenai bagaimana proses berjalannya sistem pada gambar 5, sehingga layak dijadikan optimalisasi dari sistem yang telah ada sebelumnya.

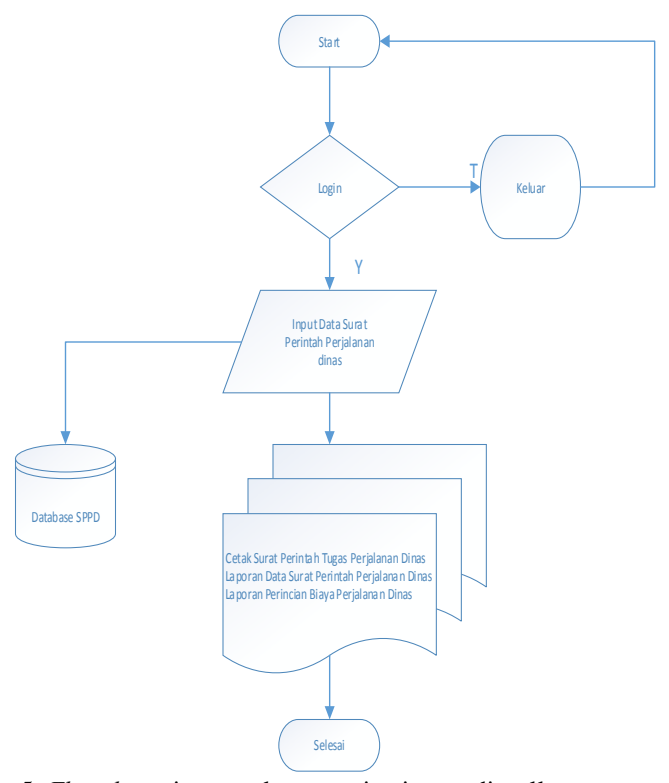

Gambar 5. Flowchart sistem terkomputerisasi yang diusulkan

Pada prosedur sistem pembuatan surat perintah perjalanan dinas terkomputerisasi yang diusulkan, dapat dilihat adanya pemangkasan prosedur yang tidak diperlukan. Prosedur yang dipangkas tersebut adalah pada bagian Kepala Sub Bagian SDM mengambil uang muka perjalanan dan melakukan validasi surat sebelum diserahkan kepada pegawai, kemudian dipangkas menjadi pegawai bersangkutan yang akan langsung mengambil uang perjalanan dinas tersebut dari bagian keuangan. Proses pembuatan surat perintah perjalanan dinas tersebut dapat dilakukan secara otomatis.

C. Analisa efisisensi sistem yang sedang berjalan dengan sistem terkomputerisasi yang diusulkan

Beberapa kelemahaan sistem yang sedang berjalan pada Kantor Regional II PT. Pos Indonesia (Persero yaitu prosedur pembuatan SPPD yang masih terdapat pekerjaan cukup panjang dan terjadi perulangan dibeberapa tempat yang harus dilalui oleh pegawai dalam pembuatan surat perintah perjalanan dinas sehingga waktu menjadi tidak efisien, dapat diperbaiki dengan pemangkasan prosedur tersebut, sehingga pembuatan surat perintah perjalanan dinas dapat dipercepat dengan menghapus/menghilangkan beberapa prosedur dan aktor yang terlibat dan pembuatan SPPD sudah tidak membutuhkan waktu yang lama. Kemudian sistem yang sebelumnya dilakukan secara sederhana dengan memanfaatkan micrsosft excell saja dan belum adanya media penyimpanan data yang terintegrasi, dapat diotomatisasi dengan menggunakan sistem terkomputerisasi dan menggunakan media penyimpanan data berupa database, dimana pemasukan data tarif uang harian biaya perjalanan dinas dilakukan secara otomatis, sehingga dapat mengurangi kesalahan dalam pembuatan dan penghitungan biaya perjalanan dinas pegawai,

\section{PENUTUP}

Dengan menggunakan sistem terkomputerisasi, proses pembuatan surat perintah perjalanan dinas dapat dilakukan secara otomatis, sehingga proses pembuatan surat perintah perjalanan dinas menjadi relatif lebih cepat. Sistem juga dapat mengurangi kesalahan dalam penghitungan biaya perjalanan dinas dengan memnfaatkan media penyimpanan berupa database. Hasil analisis proses ini dapat dilanjutkan dengan tahap perancangan dan implementasi sistem dengan menambahkan usecase diagram dan DFD sehingga keberhasian sistem dapat teruji dengan tepat

\section{REFERENSI}

[1] Saftian, widodo, 2005, Sistem Infromasi. IPWI, Jakarta.

[2] Iyan Nurbayan, Asep Deddy.S. 2015. Pengembangan Sistem Informasi Surat Perintah Perejalan Dinas (SPPD) di Balai Produksi Dan Pengujian Roket Pameungpeuk Menggunakan Netbeans. Sekolah Tinggi Teknologi.Garut. Jurnal Algoritma Sekolah Tinggi Teknologi Garut. ISSN : 2302-7339 Vol. 12 No. 1 (2015).

[3] Surat Tugas Dan Surat Perintah Perjalanan Dinas (SPPD). Tersedia : http://www.suratkerja.com/2013/03/surat-tugas-dansurat-perintah-perjalanan-dinas-sppd.html. Diakses: 28 Januari 2015, pukul 16.03 wib.

[4] Novriansyah Utama Putra. 2013.Aplikasi Surat Perintah Perjalanan Dinas Pada PT.PLN (Persero) UPK Ring SMT Regional IV Palembang. Universitas Bina Darma. Palembang

[5] Jenis-jenis Surat. http://www.zonasiswa.com/2014/01/jenis-jenissurat-lengkap.html. Diakses: 20 Februari 2015.

[6] Surat: Pengertian, Fungsi, \& Sejarah. Tersedia: http://www.zonasiswa.com/ 2013/12/surat-pengertian-fungsisejarah.html. Diakses: 20 Februari 2015.

[7] Aginta Geniusa dan Febriliyan Samopa. 2013. Pembuatan Sistem Informasi Perjalanan Dinas Kantor Wilayah Direktorat Jenderal Perbendaharaan (SIPD-Kanwil DJPBN). ITS. Surabaya. JURNAL TEKNIK POMITS Vol. 2, No. 2, (2013) ISSN: 2337-3539 (23019271 Print). 
[8] Mawardah, Sakina. Flowmap dan Flowchart Beserta Simbol. http://id.scribd.com/doc/55468895/Pengertian-Flowmap-dan-

Flowchart-Beserta-Simbol\#scribd. Diakses: 29 Januari 2015. Pukul: $13.56 \mathrm{wib}$

[9] Media, baca. Pengertian ERD (Entity Relationship Diagram). http://www.mediabaca.com/2596/pengertian-erd-entityrelationship.html. Diakses: 14 Januari 2015.

[10] Yanto, andre (2012). Pengertian dasar dan simbol flowchart. http://andreyanto-gunadarma.blogspot.com/2012/10/pengenalanflowchart-flowchart.html. Diakses: 14 Januari 2015. 